\title{
Research on Cultural Heritage and Expression of Characteristic Towns Planning and Design
}

\author{
$\mathrm{Li} \mathrm{Li}^{1, \mathrm{a}}, \mathrm{Xiao} \mathrm{Cui}^{2}$ \\ ${ }^{1}$ Architectural Engineering Department, Weifang University of Science and Technology, Facility Horticulture Laboratory of Universities \\ in ShandongShouguang, Shandong 262700, China \\ ${ }^{2}$ Architectural Engineering Department, Weifang University of Science and Technology, Shouguang, Shandong 262700, China
}

\begin{abstract}
Culture is the soul of characteristic towns, which determines the charm of the towns. The article analyzes the connotation of characteristic towns and discusses the expression and inheritance ways of culture in characteristic towns planning and design. In the process of planning and design, with the combination of viewing activities and tourism activities, the combination of culture and the Internet, digital information and intelligent green, the combination of cultural symbols and garden landscapes such as landscapes, plants, buildings, garden accessories, road paving, the article penetrates the culture into the planning field of the characteristic towns.
\end{abstract}

\section{Introduction}

The characteristic town is a developing space platform and a new type of community that is independent of the urban area and has clear industrial orientation, cultural connotation, tourism, and certain community functions. (Chen Lixu 2017) The maintenance of the community requires the establishment of a common spiritual bond, and it is even more necessary to reconstruct and strengthen the cultural cohesion that the "townspeople" have converged and linked together. The community maintenance requires the promotion of planning and design hardware construction, while enhancing cultural awareness, excavating historical and cultural connotations, strengthening cultural cohesion, highlighting cultural characteristics, and providing effective spiritual support for the construction of characteristic town.

Arthur J. Vidich and other scholars (1968) wrote in the book Small town in mass society: "College professors, administrators, and other professionals are all attracted by town's unique cultural identity that the university has endowed, thus they regard the town as an ideal place to live." This reflects the important position that culture occupies in the development of the American university town. However, due to the lack of Chinese planners and scholars 's cultural attention, some small towns are out of line with culture, the architectural styles are similar, and cultural connotation is missing in the process hardware facilities construction, which results in the lack of development momentum of characteristic town.

This article provides an analysis of the operational and feasibility dimensions for cultural inheritance and expression, and strives to improve the planning and design methods under the different conditions of cultural connotation, natural environment, and economic industry. This analysis method is conducive to promoting China's existing planning and policy system, so as to better promote the play of cultural functions. Meanwhile, it is also conducive to enhancing the cultural connotation of characteristic small towns and strengthening the people's spiritual recognition of local culture.

\section{Analysis of the connotation of the characteristic town}

\subsection{Analysis of the crowds mainly composed of enterprises, townspeople and tourists}

To a certain extent, the operation of a small town is more like the management of a small urban complex. The construction of an operation service system needs to target three groups.

\subsubsection{Enterprises}

The key to successful construction of characteristic towns is to give full play to the role of corporate market mechanisms. In reality, the characteristic towns with outstanding performances are all the result of marketization.

\subsubsection{Townspeople}

Townspeople participate in the construction and management of characteristic towns, which requires the townspeople to enhance their sense of identity and sense of belonging. 


\subsubsection{Crowd of tourists in characteristic towns}

Among characteristic towns, the characteristic towns with tourism functions occupy $60 \%$. In the process of building a characteristic town, we must work hard on the "cultural" atmosphere that visitors cannot normally experience, which achieves the success of the development of characteristic towns.

\subsection{Functional analysis led by industry, residence, tourism and culture}

The characteristic town is a new carrier for promoting innovation and entrepreneurship, which has an important role in promoting the synchronization of "three industries" and "four modernizations". The characteristic towns are characterized by characteristic industries, cultural tourism, historical inheritance, community livability, and ecological harmony, which completely break the thinking imprisonment of the "three productions" and "four modernizations".

Characteristic town is the inheriting carrier of historical and cultural communication. For some time, China's extensive urbanization model which commonly known as "unorderly sprawl" has resulted in the phenomenon of "some cities have no history" and "some cities have no civilization". However the industrial development of characteristic town pays high attention to the cultural accumulation and historical inheritance in the development of small towns, which requires to integrate historic culture into industrial development and community construction. For the small towns with cultural characteristics of tourism, the accumulation and inheritance of historical culture is required to be organic unification with the construction of cultural and tourist industry. It is essential to finding the balance point between functional agglomeration and diffusion and urbanization and counter urbanization in the field of productivity allocation of characteristic towns.

\subsection{Analysis of cultural patterns represented by regions, industries, enterprises, materials, and non-materials}

The culture is the soul of a characteristic town, which determines its character and development direction. It enables people to communicate with territory breaking the boundaries of time, and allows people to feel and appreciate various cultural inheritance and contexts. At this point, we emphasize that making it branding and visible by mining and carding of regional culture.

The scope of culture is very wide. In terms of the construction of characteristic towns, culture includes different categories such as regional culture, industrial culture, corporate culture, material, and non-material culture, which has innovative, native and fashionable features. Selecting cultural-oriented traits and using cultural -penetrated capabilities allow individual culture to penetrate into every aspect of a characteristic town. Besides, the construction and development of characteristic small towns are guided by characteristic cultures and integrated with characteristic cultures.
Based on this, they can be derived from a variety of formats and products, thereby forming a common development pattern with characteristic towns.

\subsection{Mutual relationship between cultural inheritance \& expression and characteristic towns planning}

The distribution of productivity in characteristic towns needs to find the best balance between the convergence of functions, urbanization and counter-urbanization, rural revitalization and urbanization. At the same time, we must also find the best balance between production development, cultural heritage, and ecological protection. Planning should be based on the premise and foundation of cultural heritage and expression, and cultural inheritance and expression are the carrier and expression form of featured town planning. Therefore, planning and cultural heritage are ultimately achieve common improvement with a harmonious, unified and interactive relationship.

\section{Research on cultural heritage and expression of characteristic towns planning and design}

\subsection{Research on the carrier of cultural inheritance and expression}

\subsubsection{The combination of viewing and tourism activities}

While the outstanding characteristic towns at home and abroad have a profound cultural background, its fine and unique landscape features full of art has become an important factor attracting gathering popularity, which has successfully led the local tourism industry to flourish.

The development of tourism is bound to inject fresh vitality into other indigenous industries of characteristic towns, bringing the developed opportunities for economy and industry and promoting the comprehensive development of town construction as well. At the same time, the cultural value of small towns will be reflected in the market economy, and becoming the memory symbols and important signs of town's civilization. Therefore, in the stage of characteristic towns' planning and design, taking organizing diversified and characteristic tourism activities into full consideration could provide effective ways to spread and express towns' culture.

The key to the development of tourism projects in characteristic towns is the performance of regional cultural characteristics and the shaping of ecological landscapes. Besides, visitors' visual experience is equally important in the pursuit of spiritual exploration, which means that in the planning and design stage of a characteristic town, while paying attention to the interactive and experiential tourism activity, it also fully considers and integrates into the visual aesthetic activities. 


\subsubsection{Combination of culture and internet, digital Information, and intelligent green}

The characteristic town planning should have a sense of advancement and conform to the requirements of the times. It must be positioned in the heights of the national strategy and the global perspective, which means that not only should the culture be highly refined and dialoged, but also the times pattern must be understood, and the advanced development concepts such as the Internet, electronic information technology, and intelligent green should be widely used.

The Internet represents the most advanced technology, while traditional small towns are relatively backward in the shape of cities and towns. However, the planning and design of characteristic towns requires the use of traditional spatial forms to carry advanced technologies, such as solving the problems of scattered distribution and long distance between different regions through smart means, avoiding invalid actions through the process of digital information technology, and dealing with the problem of the connection between production and living by greenization and informatization. Consequently, the characteristic towns should be provided ascendant development conditions by using advanced ideas and technologies.

\subsubsection{The combination of cultural symbols and garden landscapes such as landscapes, plants, buildings, garden accessories, road paving etc}

In some traditional small town planning, emphasis is placed on the development of space, while the consideration of style is insufficient and characteristics are not valued.

In the characteristic towns planning and design, it is very important to set more specific and detailed sections of urban design and style design. From the elements of the township, such as the external environment, the overall layout, residential neighborhoods, commercial services, street space, architectural styles, landscape green spaces, and plaza paving, etc., a design improvement plan is proposed. In order to build a characteristic town with a quality, connotation, and attractive place instead of a beautiful empty place, it is particularly important to dig, inherit, and develop culture and to apply the extracted geographical and traditional cultural symbols (history, characters, and stories) to space places. Also, we should summarize the current situation, thus inheriting and forming cultural sites with current characteristics.

\subsection{Research on cultural inheritance and expression}

\subsubsection{Cultural introduction and reservation}

Cultural genes are an important aspect of the in-depth study of the planning and design of characteristic towns. When analyzing and quoting the culture of a characteristic town at the planning stage, the following points should be noted:

First, it is necessary to fully explore distinctive cultures. Characteristics are the greatest charm of the town, and it is also the most powerful vitality of construction and development. Therefore, the distinctiveness and characteristics of the cited culture are important factors that ensure the uniqueness of the town.

Second, it is important to maintain the culture's originality and vividness. Originality refers to the natural historical and cultural features that the towns itself own, which is inherited and has a certain thickness and strength. Vividness refers to those cultural habits that have long been integrated into the lives of small town residents. Both two characteristics are the best interpretation of the town's cultural characteristics. For example, the town of Qixi in Xiang yang, Hubei Province, has preserved part of the ruins and modern restoration in the cultural experience area. In addition to the display of antique relics and sculpture archways, even the streets are paved with ancient slate slabs of the official and folk streets of the Song and Yuan Dynasties that were collected over the years. These ancient artifacts themselves carry a deep historical heritage and cultural connotations. Thus, visitors can truly experience the changes of the times and historical changes while walking. The scenery such as wet stone roads, mottled arches, Zhang Fei's ancient pavilion at the eaves corner of clear waters and arched three-hole bridge, will make visitors feel a sense of return to history.

\subsubsection{Cultural Simplification and Conversion}

As a country with a long history of civilization, all kinds of material and intangible cultural heritage are abundant. It provides high-quality and extensive cultural materials and industrial resources for inheriting and expressing the culture of characteristic towns. For example, some famous historical and cultural cities can make use of their rich material and cultural heritage to create historic and cultural towns with historical capitals, traditional styles, scenic spots, and regional features; creating myths and legends towns, drama towns, gourmet towns, Chinese medicine towns and various types of handicraft towns with characteristics of ornamental value, artistic and life quality around local topics of folklore, custom, language, music, dance, etiquette, celebration, cooking and traditional medicine.

However, from the views of the characteristic town planners, not all the remaining cultural types can be used to create the town's characteristic culture. Cultural elements such as having a certain geographical advantage, outstanding uniqueness, and a certain market development prospects, can be used so as to plan and build corresponding characteristic small towns. In other words, when the cultural heritage can be simplified into a cultural product or service that is popular with the market, the corresponding industrial system can be created to promote the development of the characteristic culture of the town. For example, Yixing teapot characteristic town in Jiangsu province and Luzhou 
Laojiao wine culture town in Sichuan province are all combined with the best quality cultural resources and modern production and life.

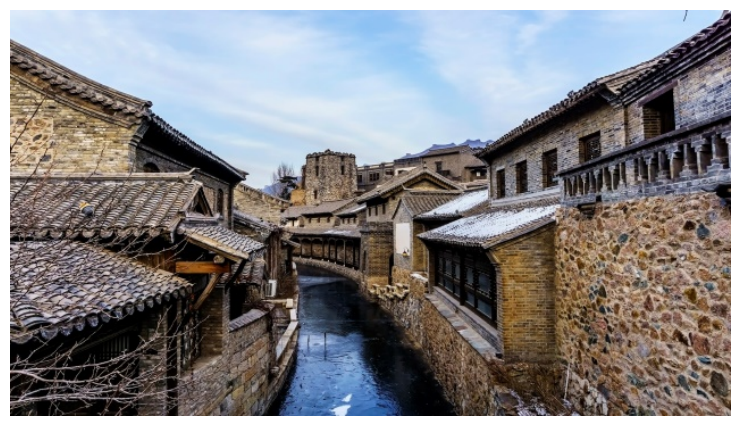

Figure 1. The landscape of Gubei Water Town

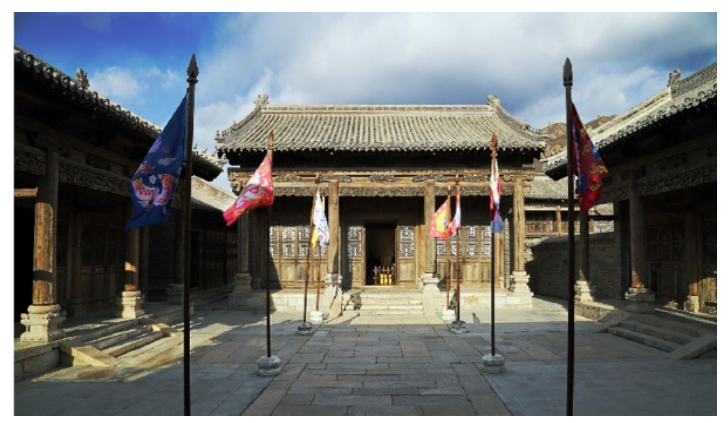

Figure 2. Baqi Hall in Gubei Water Town

\subsubsection{Cultural reproduction}

Those characteristic towns with historical and cultural heritage are important carriers for inheriting and carrying forward national culture, displaying Chinese cultural charm, and enhancing cultural self-confidence. Its soul lies in its unique historical context. To achieve cultural reappearance, it is necessary to maximize the protection of the original cultural heritage and to bring out unique local culture. For example, Gubei Water Town in Beijing (Figure 1) is a unique town built on history and culture. The reconstruction of the representative buildings such as the Great Wall College, Yang Wudi Tower, Sima xiaoshao, and the Baqi hall (Figure 2) achieved the scene creation of the northern town to the greatest extent and reproduced the history and folk culture of the northern frontier town. That is, Gubei Water Town not only protects and inherits the unique regional history and culture, but also builds its own cultural brand on this basis.

\subsubsection{Cultural symbols and metaphors}

"Making use of objects to express ideas" and "Combining emotion with scenery" is a kind of concealment expression that Chinese people are good at using since ancient times. In the planning and design of characteristic towns, integrating culture more naturally into the essence of the town requires that the planners upgrade the town's unique culture and permeate the life of the town's residents with spiritual symbols and mood expressions.

In order to reflect the neighboring culture pursued by the people in the planning and layout, the residential area of the Qixi Town, located in the Fanxi New District, creates a street experience of "step shifting and the scenery and feeling changes" that based on the scale of space and the creation of places to express the idea of cultural communication. This kind of cultural metaphor is also reflected in the architectural design of the town, such as the ups and downs of the "horse's head wall" in the courtyard, which create a visually feeling of "Ten thousand steeds gallop". At the same time, it also metaphorizes the entire clan's freshness and prosperity.

\section{Conclusion}

From the pilot stage in Zhejiang Province in 2015 to the full implementation stage in China in 2018, the construction of characteristic towns has taken a short period of time, but has been developing extremely fast. As a new thing, there is a great improvement at the planning level, and it is inevitable that there will be a phenomenon of "thousand towns and one side". However, cultural competitiveness has prompted people to take a cultural perspective and re-examine the planning of characteristic towns, thereby enhancing the cultural connotation of featured towns with ways of cultural excavation, inheritance and expression.

\section{Acknowledgments}

This work was supported in part by

Annual youth project of Shandong Province social science planning in 2017 (Grant Number 17DWYJ03), Weifang University of Science and Technology doctoral fund project (Grant Number 2017BS20), Facility Horticulture Laboratory of Universities in Shandong (Grant Number 2018YY024)

\section{References}

1. Hart, John F., 1988, "Small Towns and Manufacturing", Geographical Review, Vol.78, No.3, pp.272 - 287.

2. Vidich, Arthur J. \& Joseph B., 1968, Small Town in Mass Society, Class, Power and Religion in a Rural Community, Princeton, New Jersey: Princeton University Press, pp.334.

3. Jia Y, Ziqi R. The Collaborative Research of Beautiful Country and Characteristic Town [J]. Forum of Agriculture, Rural Areas and Rural Residents, 1(2017), pp.2-5.

4. Wei H, Chao L, and Mengran W. Consideration of the Characteristic Town Actuated by Innovation and Entrepreneurship - Summarized with Characteristic Town Investigation [J]. China Ancient City, 2(2017), pp.16-21. 
5. Qianjun W., Strategy Discussion of the Characteristic Town Planning in Perspective of CityIndustry Integration [J]. Planning Design, 9 (2016), pp.41-43.

6. Peipei Z., Yuan D., Characteristic Analysis of Characteristic Town's Creation and Planning Design [J]. Planning Design, 12 (2016), pp.57-62. 